\title{
STAGNIRA LI DOISTA SIROMAŠTVO U HRVATSKOJ?
}

Zoran ŠUĆUR

Pravni fakultet, Zagreb

UDK: 330.59(497.5)

Izvorni znanstveni rad

Primlieno: 12. 10. 2011.

Osnovni je cili ovoga rada bio usporediti stope siromaštva u Hrvatskoj dobivene na temelju službene metodologije za praćenje siromaštva u EU-u s alternativnim pokazatelijima dohodovnoga siromaštva, materijalne deprivacije i subjektivnoga siromaštva. Osim analize pokazatelja siromaštva prema pojedinim dimenzijama, primijenjen je i kumulativni pristup mjerenju siromaštva, ti. siromaštvo je mjereno prema kombinaciiji više dimenzija ili miera siromaštva. Kao izvor podataka uzeta je Anketa o potrošnji kućanstava u razdoblju od 2003. do 2008. godine. Svi alternativni pokazatelii siromaštva i pokazatelii kumulativnoga siromaštva potvrđuju da je od 2003. do 2008. došlo do osjetnoga smanjenja opsega siromaštva (stope materijalne deprivacije gotovo su prepolovljene), što je u raskoraku sa stagnantnim stopama relativnoga siromaštva (prema liniii siromaštva EU-a). Ustanovljeno je da postoji korelacija, ali ne i potpuno preklapanje između dimenzija siromaštva. Razne mjere siromaštva rezultiraju raznim profilima siromaštva. Rad je pokazao da je prilikom praćenja siromaštva nužno primijeniti više mjera siromaštva i kumulativni pristup, jer se na taj način može bolje utvrditi ne samo opseg nego i dubina siromaštva.

Ključne riječi: siromaštvo, materijalna deprivacija, kumulativni pristup, Hrvatska

Zoran Šućur, Pravni fakultet Sveučilišta u Zagrebu, Studijski centar socijalnog rada, Nazorova 51, 10000 Zagreb, Hrvatska. E-mail: zsucur@yahoo.com

\section{UVOD}

Siromaštvo u Hrvatskoj kontinuirano se mjeri unatrag desetak godina na temelju jedinstvene metodologije Statističkog ureda Europske unije (Eurostata). Naime, Državni zavod za statistiku Republike Hrvatske (DZS) provodi na godišnjoj razini 
DRUŠ. ISTRAŽ. ZAGREB GOD. 21 (2012), BR. 3 (117)

STR. 607-629

ŠUĆUR, Z.:

STAGNIRA LI DOISTA...

1 Treba podsjetiti da se još u definiciili siromaštva Vijeća ministara iz sredine 1980-ih naglašava važnost novčanih nenovčanih aspekato siromaštva. Prema to definiciii, siromašnima se smatraju "osobe čij su resursi (materijalni, kulturni i socijalni) tako ograničeni da ih isključuju iz minimalno prihvatljivog načina života zemlje članice kojoi pripadaju" (Council of Ministers, 1985.).
Anketu o potrošnji kućanstava (APK) te objavljuje ključne pokazatelje siromaštva polazeći od Eurostatove službene metodologije za praćenje siromaštva. Prema toj metodologiji, siromašnima se smatraju osobe čiji su ekvivalentni dohoci manji od $60 \%$ medijana nacionalnoga dohotka. Radi se o relativnoj liniji siromaštva, koja je, po svojoj definiciji, odraz dohodovne distribucije.

Ako na temelju spomenute linije siromaštva pratimo stope siromaštva ili "stope rizika od siromaštva" (at-risk-of-poverty rate), kako se nazivaju prema službenoj terminologiji, onda se vidi da u Hrvatskoj od 2003. do 2008. godine nije bilo gotovo nikakvih promjena u stopama siromaštva. Naime, stopa siromaštva u spomenutom razdoblju kretala se oko $17 \%$ (DZS, 2006., 2009.). Ako bismo se oslanjali samo na ovaj pokazatelj siromaštva, proizlazilo bi da je siromaštvo u Hrvatskoj stagnantno i nepromjenjivo. Ovaj podatak može biti iznenađujući kada se uzme u obzir činjenica da je Hrvatska od 2003. do 2008. imala relativno visoke stope rasta BDP-a (između 4\% i $5,5 \%$ ). Stoga je ključno pitanje na koje će pokušati odgovoriti ovaj rad: kako objasniti stagnantnost siromaštva u situaciji visokih stopa ekonomskog rasta? Je li problem u metodologiji praćenja siromaštva ili se radi o ekonomskom rastu koji nije uspio smanjiti socijalnu i ekonomsku depriviranost donjih društvenih slojeva? Pošli smo od teze da drugi ili alternativni pokazatelji siromaštva te kombinacija pokazatelja siromaštva daju cjelovitiji uvid u trendove siromaštva nego samo pokazatelji koji ovise o dohodovnim nejednakostima.

Valja istaknuti da je EU, posebice od 2004. godine, zbog uočenih manjkavosti koncepta relativnoga (dohodovnog) siromaštva nastojala pokazatelje dohodovnoga siromaštva dopuniti pokazateljima apsolutnoga siromaštva ili materijalne deprivacije. ${ }^{1} \mathrm{U}$ tom kontekstu treba razumjeti rast popularnosti koncepata socijalne isključenosti, deprivacije i višedimenzionalnoga pristupa siromaštvu i na razini članica i na razini EU-a (Guio, 2005., 2009.; Bradshaw i Finch, 2003.; Tsakloglu i Papadopoulos, 2002.a, 2002.b; Kenworty, 2007.; Whelan i sur., 2008.; Böhnke, 2008.; Tomlinson i sur., 2008.; Guio i sur., 2009.; Ayala i sur., 2009.; Bossert i sur., 2009.; Fusco i sur., 2011.; Berthoud i Bryan, 2011.). Tek od 2009. godine EU je usvojio dva nova pokazatelja materijalne deprivacije (stopa i intenzitet deprivacije), koji se temelje na 9 indikatora objektivne materijalne deprivacije: 1 . moći platiti režije, stanarinu, kredit; 2 . održati dom toplim; 3. platiti neočekivane izdatke; 4 . jesti redovito meso i proteine; 5 . otići na godišnji odmor; 6 . imati televizor; 7. imati perilicu rublja; 8 . imati automobil; 9 . imati telefon (European Commission, 2009.). Stopa deprivacije (deprivation rate) označuje udio osoba koje si ne mogu priuštiti barem 3 od navedenih 9 pokazatelja deprivacije, dok intenzitet ili dubina 
DRUŠ. ISTRAŽ. ZAGREB GOD. 21 (2012), BR. $3(117)$

STR. 607-629

ŠUĆUR, Z.: STAGNIRA LI DOISTA.. deprivacije (depth of deprivation) označuje prosječan broj pokazatelja deprivacije (od 0 do 9) koje si osobe ne mogu priuštiti. $\mathrm{Ni}$ ovih 9 pokazatelja ne pokrivaju sve aspekte ili dimenzije životnoga standarda (npr. zdravlje, zaposlenost, obrazovanje i sl.), nego se odnose uglavnom na posjedovanje trajnih kućanskih dobara i ekonomske poteškoće u održanju minimalnoga životnog standarda.

U Hrvatskoj se dosad nisu službeno pratili pokazatelji materijalne deprivacije, među ostalim i zato što se oni u zemljama EU-a temelje na EU-SILC (Community Statistics on Income and Living Conditions), koja se u Hrvatskoj dosad nije rabila prilikom praćenja pokazatelja siromaštva. Prema tome, da bismo istražili eventualne promjene $u$ životnom standardu siromašnih i provjerili povezanost između dohodovnoga siromaštva i materijalne deprivacije u Hrvatskoj, moramo se osloniti na Anketu o potrošnji kućanstava, što znači da, barem zasad, nije posve moguće uspoređivati pokazatelje materijalne deprivacije $\mathrm{u}$ Hrvatskoj s onima u zemljama EU-a. No najprije ćemo objasniti mjere i pokazatelje koji se mogu rabiti kao alternativa i/ili dopuna pokazateljima dohodovnoga siromaštva.

Nastavak rada sastoji se od četiri poglavlja. U prvom se razjašnjavaju teorijski koncepti i mjere siromaštva. Nakon toga definirani su ciljevi istraživanja i objašnjeni istraživački instrumenti. U središnjem poglavlju rada izloženi su i raspravljeni glavni nalazi rada, a u zaključnom poglavlju najvažniji rezultati, uspoređeni s rezultatima drugih istraživanja.

\section{KONCEPTI SIROMAŠTVA I MATERIJALNE DEPRIVACIJE}

Pojam siromaštva podrazumijeva situaciju u kojoj pojedinci nemaju materijalnih ili financijskih resursa da bi zadovoljili potrebe opstanka (apsolutno siromaštvo) ili potrebe koje čine sastavni dio minimalno pristojnoga standarda $\mathrm{u}$ društvu $\mathrm{u}$ kojem žive (relativno siromaštvo). EU manje zanima koncept apsolutnoga siromaštva, jer je za većinu zemalja ključan izazov kako omogućiti svim građanima da uživaju u dobrobiti koja je rezultat visokoga ekonomskog prosperiteta, a ne da osiguraju podmirenje temeljnih životnih potreba. Ipak, neki autori upozoravaju da treba pratiti učinke mjera socijalne politike i na relativno i na apsolutno siromaštvo, jer u većini zemalja EU-a postoji tek djelomično preklapanje između grupa koje žive $u$ apsolutnom i relativnom siromaštvu, a u manje razvijenim članicama EU-a troškovi minimalne košarice mogu biti iznad linije relativnoga siromaštva (Notten i Neubourg, 2007.).

Osim preferiranja relativnoga siromaštva, EU je prihvatio "indirektan" pristup mjerenju siromaštva (Ringen, 1988.; Halleröd, 1995.; Perry, 2002.), tj. težište je na financijskim resursima kojima raspolažu pojedinci ili kućanstva, s tim da se ti resursi uglavnom svode na dohodak. Stoga se takvo siromaš- 
DRUŠ. ISTRAŽ. ZAGREB GOD. 21 (2012),

BR. 3 (117),

STR. 607-629

ŠUĆUR, Z.:

STAGNIRA LI DOISTA... tvo i naziva "dohodovno siromaštvo" (income poverty). Međutim, dohodak je samo jedna komponenta financijskih i materijalnih resursa, tako da dohodovno siromaštvo često ne uzima u obzir neprijavljeni dohodak, ušteđevinu i drugu imovinu, naturalni dohodak i sl. Očito da je "raspoloživi dohodak" nesavršena mjera siromaštva. Stoga se smatra poželjnim kombinirati indirektni i direktni pristup mjerenju siromaštva. Direktni je pristup usmjeren na nemonetarne pokazatelje, odnosno na životni standard što ga pojedinci uživaju. Drugim riječima, "siromaštvo se mjeri preko posljedica koje nastaju nakon prevođenja ekonomskih resursa u elemente životnog standarda" (Šućur, 2001., 97). Nenovčani pokazatelji materijalne deprivacije upravo predstavljaju direktni pristup mjerenju siromaštva.

Prvi pokušaji upotrebe materijalne deprivacije u mjerenju siromaštva najčešće se vezuju uz britanske istraživače P. Townsenda (1979.) te Macka i Lansleyja (1985.). Za Townsenda (1979.), siromaštvo znači manjak financijskih resursa koji su potrebni da bi se izbjegla deprivacija i osigurali životni uvjeti koji su poželjni u određenom društvu. Prilikom istraživanja siromaštva naglasak je na materijalnoj deprivaciji, iako se može istraživati i socijalna deprivacija (npr. sudjelovanje u obiteljskim i socijalnim mrežama), ali nju je znatno teže mjeriti nego materijalnu. Fusco i sur. (2011., 1) definiraju materijalnu deprivaciju kao "nemogućnost posjedovanja dobara, pristupa uslugama i/ili nemogućnost sudjelovanja u aktivnostima koje su uobičajene u društvu ili su društveno prihvaćene kao 'nužne"'.

Postoji niz poteškoća i problema prilikom operacionalizacije koncepta materijalne deprivacije. Konstrukcija pokazatelja ili indeksa materijalne deprivacije uključuje tri ključna koraka (Guio i sur., 2009.; Fusco i sur., 2011.): 1) odabir pokazatelja deprivacije, 2) grupiranje pokazatelja prema dimenzijama deprivacije te 3 ) agregiranje podataka u jedan ili više indeksa deprivacije. Na svakom od spomenutih koraka istraživači su prisiljeni donositi niz arbitrarnih odluka. Prije svega, nema usuglašenoga skupa indikatora materijalne deprivacije koji bi se rabio u međunarodnim ili nacionalnim istraživanjima. Izbor indikatora ovisi o tome što želimo mjeriti i može se temeljiti na teorijskim i/ili empirijskim kriterijima. Međutim, budući da istraživači nerijetko rabe podatke iz istraživanja koje nisu sami provodili, taj odabir ovisi o tome koji su pokazatelji uopće dostupni. S obzirom na to da nas zanima fenomen siromaštva, pokazatelji materijalne deprivacije mogu odražavati isključenost (zbog nedostatka financijskih resursa) iz minimalno prihvatljiva životnoga standarda ili nekoga egzistencijalnog minimuma. No nije jednostavno odgovoriti na pitanje što razumijevati pod minimalno prihvatljivim životnim standardom ili egzistencijalnim minimumom. Jedna je 
DRUŠ. ISTRAŽ. ZAGREB GOD. 21 (2012),

BR. $3(117)$

STR. 607-629

ŠUĆUR, Z.:

STAGNIRA LI DOISTA... mogućnost da to prepustimo stručnjacima, ali i oni mogu biti pristrani i nametati vlastite "prosudbe". Druga je mogućnost da odabir pokazatelja deprivacije prepustimo javnosti, da ispitanici procijene koji su pokazatelji nužni za egzistencijalni minimum ili minimalno prihvatljiv životni standard (tzv. konsensualni pristup). Primjer drugoga pristupa predstavlja već "klasična" studija "Poor Britain" Macka i Lansleyja (1985.), u kojoj su ispitanicima prepustili da sami odaberu s podužega popisa predmete, usluge i aktivnosti koje smatraju nužnima ili prijeko potrebnima. Na kraju su na popis uvršteni oni pokazatelji deprivacije koje je barem $50 \%$ ispitanika smatralo nužnima za prihvatljiv životni standard. Autori čak smatraju da konsenzus o pokazateljima deprivacije treba postići među socijalnim skupinama (homogenost preferencija). S druge strane, P. Townsend skloniji je prvom pristupu i smatra da se znanstvenici ne smiju zadovoljiti "konsensualnim procjenama", odnosno da se kriteriji potreba i deprivacije trebaju tražiti izvan granica socijalne percepcije. "Temeljni je problem u tome da neke potrebe zajednice mogu ostati nezamijećene od članova te zajednice ili mogu biti zamijećene od strane nekolicine ili mogu biti općenito zanemarene. Ponašanje ljudi može otkriti ono što se smatra nužnim, čak i onda kada ljudi nisu uvjereni da je to tako" (Townsend i Gordon, 1991., 45).

Nakon odabira pokazatelja deprivacije ostaje pitanje njihove analize i interpretacije. Jedna je mogućnost da se svaki pokazatelj deprivacije analizira zasebno. Međutim, na taj je način teško steći cjelovitu sliku deprivacije. Poželjnije bi bilo grupirati pokazatelje deprivacije prema relevantnim i homogenim dimenzijama, tako da možemo pratiti i analizirati promjene u pojedinim dimenzijama deprivacije. Pokazatelji deprivacije mogu se grupirati arbitrarno, prema nekim aspektima ili područjima životnoga standarda (npr. da jednu dimenziju čine svi pokazatelji koji se tiču stanovanja) ili na temelju empirijskih podataka (npr. koristeći se faktorskom analizom).

Naposljetku, pokazatelji deprivacije mogu se agregirati u jedan indeks ili u nekoliko indeksa deprivacije (npr. indeksi deprivacije po dimenzijama i sumarni indeks deprivacije). Ima i onih, poput M. Ravalliona, koji smatraju da je konstrukcija kompozitnog indeksa deprivacije metodološki i spoznajno promašena, jer nema suglasnosti o tome kakvu težinu pridati pojedinoj dimenziji deprivacije (vidi: http://www.oxfamblogs. org/fp2p/?p=3070). Ako se pristupi konstrukciji indeksa deprivacije, najprije se pojavljuje pitanje kakvu važnost pridati pojedinim pokazateljima prilikom izračuna takvih indeksa. Najjednostavnije je svim pokazateljima pripisati jednaku težinu (ponder), tako se razina materijalne deprivacije mjeri preko broja pokazatelja. Prednost ovoga pristupa jest u jednostavnosti interpretiranja podataka, a nedostatak $u$ tome što 
DRUŠ. ISTRAŽ. ZAGREB GOD. 21 (2012),

BR. 3 (117),

STR. 607-629

ŠUĆUR, Z.:

STAGNIRA LI DOISTA... se ne pravi razlika među pokazateljima te je moguće dvostruko brojenje ako se pokazatelji preklapaju (Guio i sur., 2009.). Alternativni pristup sastoji se $\mathrm{u}$ davanju različite težine pokazateljima deprivacije, tako da različito utječu na konačne indekse. Uglavnom se rabe dva načina "utežavanja": pristup prevalencije (učestalosti pojavljivanja) i konsensualni pristup (vidi Guio, 2009.). Prvi pristup temelji se na učestalosti posjedovanja određenoga pokazatelja u populaciji. Svaki se pokazatelj ponderira prema udjelu (proporciji) pojedinaca koji ga posjeduju ili imaju pristup tom dobru, usluzi ili aktivnosti (npr. Tsakloglou i Papadopoulos, 2002.a, 2002.b.; Whelan i sur., 2001.; Dickes i sur., 2010.; Desai i Shah, 1988.). Što je manji udio stanovništva bez određenoga dobra, to je veća vjerojatnost da će se osoba koja si ne može priuštiti dotično dobro osjećati depriviranom. Konsensualni pristup pridaje važnost pojedinom pokazatelju na temelju socijalnih prosudbi ili prosudbi javnosti o tome što je nužno da bi osoba živjela pristojnim životom. Rezultati analize materijalne deprivacije mogu uvelike ovisiti o metodi ponderiranja. Može se dogoditi da neko dobro posjeduje malen dio stanovništva (pa će dobiti mali ponder prema pristupu prevalencije), ali ga velika većina stanovništva smatra nužnim za minimalno pristojan životni standard (što znači da bi to dobro imalo značajnu težinu prema konsensualnom pristupu).

Dohodovno siromaštvo i materijalnu deprivaciju ne treba gledati kao konkurentske nego kao komplementarne koncepte. Mnoga su istraživanja na razini EU-a i zemalja članica potvrdila postojanje povezanosti između ova dva koncepta, iako ta veza nije savršena, linearna ni monotonijska (Berthoud i Bryan, 2011.; Whelan i sur., 2003., 2004:, Fusco i sur., 2011.; Bradshaw i Finch, 2003.). Pokazatelji siromaštva koji se temelje isključivo na dohotku ne odražavaju u dovoljnoj mjeri raznolikost životnih uvjeta siromašnih. Međutim, financijski resursi i dohodak i dalje ostaju središnja komponenta siromaštva.

\section{METODE ISTRAŽIVANJA}

\section{Ciljevi istraživanja}

S obzirom na to da nema jedinstvene ni posve savršene mjere siromaštva, važno je rabiti razne metodološke instrumente kako bi se istražili aspekti siromaštva kao višedimenzionalnoga fenomena. Već su odavno uočene slabosti koncepta dohodovnoga siromaštva i relativne linije siromaštva, pa se pojavila potreba za dodatnim pokazateljima siromaštva, kao što su pokazatelji materijalne deprivacije. Uzimajući u obzir neočekivanu činjenicu da je relativno siromaštvo u Hrvatskoj od 2003. do 2008. ostalo nepromijenjeno unatoč ekonomskom rastu, sljedeći su ciljevi rada: 
DRUŠ. ISTRAŽ. ZAGREB GOD. 21 (2012), BR. $3(117)$

STR. 607-629

ŠUĆUR, Z.

STAGNIRA LI DOISTA...
1) usporediti stope siromaštva u Hrvatskoj dobivene na temelju Eurostatove linije siromaštva (60\% medijana nacionalnoga dohotka) s alternativnim pokazateljima dohodovnoga siromaštva, materijalne deprivacije i subjektivnoga siromaštva,

2) utvrditi opseg siromaštva primjenjujući kumulativni pristup (kombinirajući više mjera siromaštva),

3) istražiti razlike $u$ obilježjima pojedinaca i kućanstava $s$ obzirom na kombinaciju dimenzija siromaštva.

\section{Mjerenje siromaštva i materijalne deprivacije}

\section{Objektivno siromaštvo}

Objektivno siromaštvo mjereno je na temelju metodologije Eurostata. To znači da je primijenjen koncept raspoloživoga dohotka, službena metodologija za praćenje siromaštva u EU-u i modificirana OECD-ova ekvivalentna ljestvica. Raspoloživi dohodak kućanstva pretvoren je u ekvivalentni dohodak na temelju OECD-ove ljestvice, koja prvom odraslom članu kućanstva pripisuje koeficijent 1 , drugim odraslim članovima 0,5 , a djeci mlađoj od 14 godina koeficijent 0,3 . Siromašnom se smatra ona osoba čiji je ekvivalentni dohodak manji od $60 \%$ medijana nacionalnoga dohotka. Tako se određuje relativna linija siromaštva u svakoj godini promatranog razdoblja. Problem je relativne linije siromaštva u tome što stope siromaštva odražavaju nejednakosti u distribuciji dohodaka ili u jednom dijelu te distribucije, tako da se smanjenje relativnoga siromaštva ne može ostvariti bez promjena u samoj dohodovnoj distribuciji.

Stoga smo dohodovno siromaštvo željeli pratiti i na temelju linije siromaštva koja se fiksira u određenoj vremenskoj točki. Drugim riječima, definira se prag siromaštva prema prije spomenutoj liniji siromaštva EU-a (60\% medijana) na početku razdoblja u kojem se želi pratiti kretanje siromaštva, a zatim se tako određena linija siromaštva u kasnijim godinama samo usklađuje s rastom troškova života ili inflacijom (umjesto da se izračunava u svakoj godini razdoblja). Linija siromaštva fiksirana u vremenskoj točki odražava životni standard na početku praćenog razdoblja, uzima u obzir promjene $\mathrm{u}$ troškovima života, ali ne prati promjene u općem (prosječnom) životnom standardu. Polazimo li od ovako određene linije siromaštva, smanjenje siromaštva može se postići zahvaljujući samo ekonomskom rastu, bez promjena u dohodovnoj distribuciji.

\section{Subjektivno siromaštvo}

S obzirom na to da smo kao izvor podataka uzeli Anketu o potrošnji kućanstava, subjektivno siromaštvo mjerili smo ovim pitanjem: "Prema raspoloživome mjesečnom dohotku, ocije- 
DRUŠ. ISTRAŽ. ZAGREB GOD. 21 (2012),

BR. $3(117)$

STR. 607-629

ŠUĆUR, Z:

STAGNIRA LI DOISTA... nite kako živi Vaše kućanstvo". Ispitanici su mogli odabrati jedan od mogućih 6 odgovora: 1. Vrlo teško, 2. Teško, 3. S malim poteškoćama, 4. Uglavnom dobro, 5. Dobro i 6. Vrlo dobro. Siromašnima smo smatrali one koji su izjavili da žive "teško" ili "vrlo teško".

\section{Materijalna deprivacija}

U ovom je radu materijalna deprivacija mjerena na 15 pokazatelja (Tablica 1). Njihov je odabir u velikoj mjeri odredila struktura upitnika u APK-u. Oni se dijelom preklapaju sa 9 pokazatelja materijalne deprivacije koji se rabe u službenoj statistici EU-a. Naime, pokazatelji deprivacije EU-a odražavaju koncept minimalno prihvatljivoga životnog standarda i sve pokazatelje većina građana EU-a smatra nužnima ili apsolutno nužnima, tako da postoji konsenzus oko tih pokazatelja (European Commission, 2007.). Pokazatelji materijalne deprivacije u ovom istraživanju odražavaju ne samo egzistencijalni minimum nego i elemente minimalno pristojnoga životnog standarda. Prilikom odabira pokazatelja materijalne deprivacije u slučaju Hrvatske nije se mogao primijeniti konsensualni pristup, jer APK ne sadrži pitanja o važnosti pojedinih pokazatelja za minimalni životni standard. Međutim, takve smo informacije za neke pokazatelje deprivacije pronašli $\mathrm{u}$ istraživanju Eurobarometra iz 2007. (European Commission, 2007.). Tako više od polovice hrvatskih građana smatra apsolutno nužnim ili nužnim sljedeće pokazatelje: WC u stanu, kupaonica ili kada u zasebnoj prostoriji, imati dovoljno svjetla/topline u stanu, živjeti u stanu bez vlage, živjeti u stanu u kojem je dovoljno prostora za privatnost svakoga člana (naš pokazatelj: imati više od 10 kvadrata po članu), održavati stan i namještaj (dotrajalost stana), posjedovati hladnjak, perilicu rublja, automobil, fiksni telefon, televizor. Pokazatelj - živjeti u susjedstvu bez nasilja, vandalizma ili kriminala, iako ga nužnim smatra više od polovine građana, nismo mogli uzeti jer ga nema u svim upitnicima APK-a od 2003. do 2008. S druge strane, s obzirom na to da ga manje od 50\% građana smatra nužnim, iz analize materijalne deprivacije isključili smo osobno računalo, ali i dva pokazatelja koja je većina građana smatrala nužnima (živjeti u području bez previše buke; živjeti u području bez prevelikoga zagađenja zraka ili okoline), zato što su značajnije smanjivali razinu unutrašnje povezanosti pokazatelja deprivacije, tj. visinu Cronbachova alfa koeficijenta. Preostale pokazatelje iz Tablice 1 (imati struju, vodovod, kanalizaciju, video/DVD), za koje nismo imali informacija $\mathrm{u}$ istraživanju Eurobarometra, odabrali smo koristeći se pristupom prevalencije: zato što ih posjeduje barem $50 \% \mathrm{ku}-$ ćanstava/stanovništva (na temelju toga kriterija, među pokazatelje deprivacije nismo uvrstili perilicu posuđa, mikrovalnu 
T TABLICA 1 Pokazatelji materijalne deprivacije pećnicu ili posjedovanje centralnoga grijanja). Da bismo provjerili unutrašnju povezanost pokazatelja materijalne deprivacije, uzeli smo Cronbachov alfa, koji iznosi 0,73.

$\begin{aligned} \text { 1) } & \text { WC u stanu } \\ \text { 2) } & \text { Dovoljno svjetla/topline u stanu } \\ \text { 3) } & \text { Više od } 10 \text { kvadrata po članu } \\ \text { 4) } & \text { Vodovod } \\ \text { 5) } & \text { Struja } \\ 6) & \text { Kanalizacija } \\ \text { 7) } & \text { Telefon } \\ \text { 8) } & \text { Kupaonica kao zasebna prostorija } \\ \text { 9) } & \text { Vlažnost stana } \\ \text { 10) } & \text { Dotrajalost stana } \\ \text { 11) } & \text { Automobil } \\ \text { 12) } & \text { Televizor } \\ \text { 13) } & \text { Perilica rublja } \\ \text { 14) } & \text { Hladnjak } \\ \text { 15) } & \text { Video/DVD }\end{aligned}$

Velika je arbitrarnost $\mathrm{i}$ kod određivanja praga materijalne deprivacije, što ovisi i o tome koristimo li se neponderiranima ili ponderiranima pokazateljima. U prvom slučaju, svaki pokazatelj ima istu težinu (ponder), pa smo među materijalno deprivirane uključili sve one kojima nedostaje 4 ili više od 15 pokazatelja (odnosno, čiji je broj pokazatelja manji od $85 \%$ medijana). Prilikom određivanja praga deprivacije koristili smo se strožim kriterijem, jer se radi o materijalnim dobrima koja posjeduje velika većina kućanstava. Osim toga, dodatne su analize pokazale da je udio ispitanika kojima nedostaje 4 i više pokazatelja vrlo malen (manji od $2 \%$ ) u gornjem dohodovnom kvartilu (među $25 \%$ ispitanika s najvišim dohotkom). Udio osoba koje nemaju 4 ili više pokazatelja predstavlja stopu materijalne deprivacije, dok je intenzitet deprivacije definiran kao prosječan broj pokazatelja koji nedostaje materijalno depriviranim osobama. Pokazatelji su u ovom slučaju bivarijatne (dummy) varijable: onima koji posjeduju određeno dobro ili nemaju određeni stambeni problem dodjeljuje se 1, a 0 onima koji ne posjeduju dobro ili imaju stambeni problem.

Također smo konstruirali indekse deprivacije koristeći se ponderiranjima prema modelu prevalencije, s obzirom na to da ne znamo za neke pokazatelje jesu li nužni za minimalno pristojni životni standard prema mišljenju građana. Svakom ispitaniku čije kućanstvo posjeduje određeno dobro ili nema određenoga stambenog problema pripisana je težina koja odgovara proporciji svih ispitanika koji posjeduju dotično dobro, odnosno nemaju stambeni problem. Ispitanici koji ne posjeduju dobro ili imaju stambeni problem dobili su koeficijent 0 . Ako npr. određeno dobro posjeduje velika većina gra- 
DRUŠ. ISTRAŽ. ZAGREB GOD. 21 (2012)

BR. 3 (117)

STR. 607-629

ŠUĆUR, Z.:

STAGNIRA LI DOISTA.. đana u Hrvatskoj, dobit će veću težinu (ponder) nego dobra koja posjeduje manji udio građana. Algoritam za izradbu deprivacijskog indeksa izgleda ovako (vidi Tsakloglou i Papadopoulos, 2002.a, 2002.b):

$$
\text { Deprivacijski bodovi }=\frac{\sum_{i=1}^{I} W_{i} X_{i j}}{\sum_{i=1}^{I} W_{i}}
$$

gdje je:

$$
\begin{aligned}
I= & \text { ukupan broj pokazatelja, } \\
W_{i}= & \text { proporcija stanovništva koja posjeduje pokazatelj } i, \\
X_{i j}= & \text { varijabla koja ima vrijednost } 0 \text { ako ispitanik nema } \\
& \text { pokazatelj ili } 1 \text { ako ga posjeduje. }
\end{aligned}
$$

Bodovna distribucija je normalizirana. Indeksni bodovi za svakog ispitanika izračunaju se tako da se zbroje težine (ponderi) za svih 15 pokazatelja i dobiveni zbroj podijeli s maksimalno mogućim brojem bodova za sve pokazatelje. Teoretski, zbirni indeksni bodovi mogu se kretati od 0 do 1 . Konačno, treba odabrati prag na distribuciji indeksnih bodova ispod kojega će ispitanici biti smatrani depriviranima. Taj smo prag, isto kao i kod neponderiranih podataka, odredili prilično strogo, tako da su depriviranima smatrani oni čiju su ukupni bodovi manji od $85 \%$ medijana na bodovnoj distribuciji.

Da bi se preciznije i objektivnije mjerila materijalna deprivacija, bilo bi važno znati je li neposjedovanje određenoga materijalnog dobra posljedica financijske oskudice ili osobnih preferencija i ukusa. Moguće je da neka dobra (npr. automobil) pojedinci nemaju zato što ih ne žele, a ne zato što ih sebi ne mogu priuštiti. Mi u ovom istraživanju nismo imali takvih informacija da bismo mogli razdvojiti utjecaj ukusa/preferencija od ekonomske oskudice.

\section{Uzorak i izvor podataka}

Kao izvor podataka uzeli smo Anketu o potrošnji kućanstava u razdoblju od 2003. do 2008. godine. Radi se o metodološkom instrumentu kojim se prikupljaju podaci o potrošnji i dohocima kućanstava te podaci o društveno-ekonomskim karakteristikama kućanstava. Anketa se provodi godišnje na uzorku privatnih kućanstava u Hrvatskoj, a u skladu s preporukama Eurostata. Anketa je reprezentativna na nacionalnoj razini (o načinu izbora uzorka i provedbi ankete, vidjeti http:// www.dzs.hr). 


\section{REZULTATI I RASPRAVA}

\section{Dinamika siromaštva i materijalne deprivacije u Hrvatskoj}

Stope relativnoga siromaštva od 2003. do 2008. godine iznosile su između 17\% i 18\% (Slika 1). U istom razdoblju stope rasta BDP-a bile su od 4,3\% do 5,5\%, osim u 2008. godini, kada Hrvatska ulazi u recesijsko razdoblje. Kako objasniti stagnantnost siromaštva u situaciji izraženoga ekonomskog rasta? $\mathrm{S}$ jedne strane, postoji mogućnost da su od ekonomskog rasta korist imale primarno skupine koje ne žive u siromaštvu. Naime, moguće je ostvariti zavidan ekonomski rast bez značajnijega novog zapošljavanja ili je novo zapošljavanje ostvareno prije svega u sektorima s niskim zaradama, što znači da bi u tom slučaju više profitirali oni koji su već zaposleni ili imaju povoljniju poziciju na tržištu rada. S druge strane, možda je koncept relativnoga siromaštva nedovoljno pouzdana mjera siromaštva koja ne odražava stvarne promjene u životnom standardu. Naime, s obzirom na to da se linija relativnoga siromaštva (definirana kao 60\% medijana) izvodi iz dohodovne distribucije, poboljšanja materijalnoga životnog standarda najsiromašnijih neće se vidjeti ako se ne dogode promjene u samoj dohodovnoj distribuciji. Tako je uočeno od sredine 2000-ih, nakon ulaska bivših socijalističkih zemalja u EU, da su neke od tih zemalja (npr. Češka, Slovačka, Mađarska) imale niže stope relativnoga siromaštva od ekonomski razvijenijih starih članica. Kako svaka zemlja ima vlastitu granicu siromaštva, slabije razvijene tranzicijske zemlje imale su znatno niže pragove siromaštva, što je rezultiralo i nižim stopama siromaštva. Osim toga, relativna linija siromaštva mjeri dohodovno siromaštvo, ne uzima u obzir druge resurse kojima kućanstva raspolažu, tako da ne odražava višedimenzionalnu prirodu siromaštvu (problem siromaštva ne može se svesti samo na problem niskoga dohotka).

S obzirom na povezanost relativnoga siromaštva i dohodovnih nejednakosti, najprije treba vidjeti što se događalo $s$ nejednakostima u promatranom razdoblju. Prema podacima DZS-a (2006., 2009.), razina nejednakosti mjerena Ginijevim koeficijentom od 2003. do 2008. ostala je ista (Ginijev koeficijent $=0,29$ ), osim u 2006. i 2007. godini, kada je Ginijev koeficijent iznosio 0,28 . To znači da male i ne baš lako objašnjive oscilacije u stopama relativnoga siromaštva u pojedinim godinama zapravo odražavaju vrlo stabilnu razinu dohodovnih nejednakosti u Hrvatskoj. Drugim riječima, moguće je da siromašni poboljšaju svoj materijalni položaj, iako su nejednakosti ostale nepromijenjene. To ćemo pokušati provjeriti uz pomoć drugih alternativnih pokazatelja siromaštva.

Kako su strukturni čimbenici povezani s tržištem rada ključni uzročnici siromaštva te kako sve zemlje nastoje eko- 
DRUŠ. ISTRAŽ. ZAGREB GOD. 21 (2012)

BR. $3(117)$

STR. 607-629

ŠUĆUR, Z:

STAGNIRA LI DOISTA..

(1) SLIKA 1

Pokazatelii relativnoga i subjektivnoga siromaštva u Hrvatskoi (od 2003. do 2008.) nomskim i socijalnim mjerama poticati zapošljavanje, ekonomski rast je preduvjet učinkovite politike zapošljavanja. Stoga bi bilo korisno pratiti siromaštvo na temelju linije siromaštva koja neće primarno ovisiti o smanjenju ili povećanju dohodovnih nejednakosti. Takav je pokazatelj stopa siromaštva koja se temelji na liniji siromaštva fiksiranoj u određenoj vremenskoj točki, tako da se na taj način može analizirati utjecaj ekonomskog rasta na siromaštvo. Kao što možemo vidjeti iz Slike 1, visoke stope rasta BDP-a od 2003. do 2007. rezultirale su smanjenjem stope siromaštva fiksirane u 2003. godini za gotovo 5 postotnih bodova. Isto tako, kada se stopa ekonomskog rasta prepolovila u 2008. u odnosu na prethodne godine, zaustavio se trend smanjivanja stope siromaštva na temelju linije fiksirane u 2003. godini.

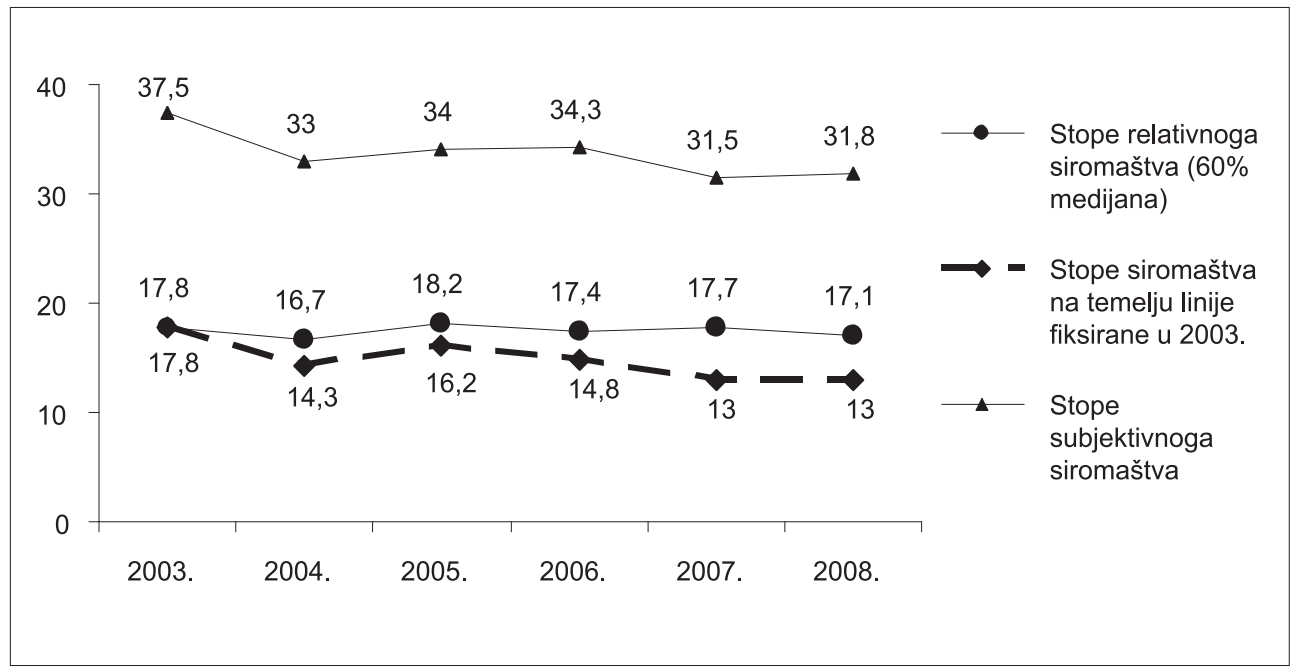

Napomena: Stope relativnoga siromaštva u ovom radu nešto se razlikuju od stopa siromaštva objavljenih u priopćenjima DZS-a (2006., 2009.). Razlozi mogu biti u statističkim procedurama, prije svega u načinu unošenja podataka koje predstavnici kućanstava nisu željeli/mogli dati (missing data) ili u nejednakom tretiranju nekih komponenti dohotka. Izvor: APK, autorovi izračuni.

Osim toga, da bismo provjerili što se događalo sa siromaštvom od 2003. do 2008. godine, koristili smo se i pokazateljima subjektivnoga siromaštva. Subjektivno siromašnima smatramo one koji su izjavili da s raspoloživim dohotkom žive "vrlo teško" ili "teško" (vidi poglavlje o metodama istraživanja). I pokazatelji subjektivnoga siromaštva sugeriraju da je od 2003. do 2008. došlo do ublažavanja siromaštva: stopa subjektivnoga siromaštva smanjena je za oko 6 postotnih bodova (Slika 1). Čak i ako se služimo restriktivnijom definicijom, pa među subjektivno siromašne uključimo samo one koji su odgovorili da žive "vrlo teško", stopa siromaštva smanjena je sa $11,2 \%$ u 2003. na $9,9 \%$ u 2008. godini. 
DRUŠ. ISTRAŽ. ZAGREB GOD. 21 (2012), BR. $3(117)$

STR. 607-629

ŠUĆUR, Z.: STAGNIRA LI DOISTA..

(1) TABLICA 2

Stope i intenzitet materijalne deprivaciie u Hrvatskoj: od 2003. do 2008 .
Međutim, subjektivne percepcije siromaštva često su "čvršće povezane s obrascima imitacije referentnih grupa nego s financijskim mogućnostima", tj. građani se teško postavljaju u poziciju neutralnog eksperta koji procjenjuje vlastiti dohodovni minimum polazeći od nekakvoga "standarda opstanka" (Šućur, 2006.a, 246), a linija siromaštva koja je fiksirana u vremenskoj točki ne prati promjene koje se događaju u pristojnom životnom standardu. Zato ćemo dodatno provjeriti preko pokazatelja objektivne materijalne deprivacije je li smanjenje stope subjektivnoga siromaštva i stope siromaštva na temelju linije siromaštva fiksirane $u$ vremenskoj točki značilo i poboljšanje stvarnih životnih uvjeta građana.

2003. 2004. 2005. 2006. 2007. 2008.

Stope materijalne deprivacije (neponderirani podaci)

Svi

Dohodovno nesiromašni

$14,4 \quad 13,0 \quad 11,4 \quad 9,5 \quad 8,9 \quad 7,2$

$\begin{array}{rrrrrr}8,3 & 7,5 & 6,8 & 5,4 & 4,5 & 3,5\end{array}$

Dohodovno siromašni

Stope materijalne deprivacije (ponderirani podaci)

Svi

Dohodovno nesiromašni

Dohodovno siromašni

$42,5 \quad 40,6 \quad 32,0 \quad 29,5 \quad 29,2 \quad 25,1$

Intenzitet materijalne deprivacije:

prosječan broj pokazatelja koje si ne mogu priuštiti materijalno deprivirani (od ukupno 15)

Napomena: Distinkcija između dohodovno siromašnih i nesiromašnih temelji se na Eurostatovoj relativnoj liniji siromaštva. Dohodovno siromašni jesu oni čiji su ekvivalentni dohoci manji od 60\% medijana nacionalnoga dohotka. Izvor: APK, autorovi izračuni.

Stope materijalne deprivacije, bez obzira na to koristili se ponderiranim ili neponderiranim podacima, nedvosmisleno pokazuju da je od 2003. do 2008. došlo do kontinuiranoga smanjenja razine materijalne depriviranosti svih slojeva stanovništva, pa tako i građana koji su bili dohodovno siromašni (Tablica 2). Konkretno, stopa materijalne deprivacije ukupnoga stanovništva, ali i dohodovno siromašnih, gotovo je prepolovljena u 2008. u odnosu na 2003. godinu. Osim toga, zamjetno je da su stope materijalne deprivacije padale kontinuirano, iz godine $\mathrm{u}$ godinu. $\mathrm{U}$ tom pogledu postoji velik raskorak između pokazatelja dohodovnoga siromaštva i pokazatelja materijalne deprivacije. Na primjer, dok je stopa dohodovnoga siromaštva u 2005. porasla u relativnom smislu za $9 \%$ u odnosu na 2004., $u$ istom razdoblju stopa materijalne deprivacije $u$ relativnom iznosu smanjena je za oko $12 \%$. Izraženi pad stopa materijalne deprivacije može se dijelom objasniti i time 
DRUŠ. ISTRAŽ. ZAGREB GOD. 21 (2012)

BR. $3(117)$

STR. 607-629

ŠUĆUR, Z.:

STAGNIRA LI DOISTA... životni standard u Hrvatskoj nego "apsolutnu jezgru" toga standarda (infrastruktura, potrošna dobra i uvjeti stanovanja). Nedostaju pokazatelji koji više mjere socijalnu participaciju, slobodno vrijeme ili rekreaciju, koji su manje povezani s konceptom preživljavanja. S obzirom na uočene razlike između dohodovnoga siromaštva i materijalne deprivacije, u sljedećem poglavlju rada pozabavit ćemo se pitanjem povezanosti ili preklapanja između promatranih mjera siromaštva. S obzirom na to da smo ustanovili kako postoji visoka korelacija između indeksa materijalne deprivacije dobivenih na ponderiranim i neponderiranim podacima $(\mathrm{r}=0,97 ; \mathrm{p}<0,01)$ te da su stope deprivacije slične, u nastavku rada uzet ćemo samo jedan indeks koji se temelji na ponderiranim podacima.

\section{Preklapanja između siromaštva i materijalne deprivacije}

S obzirom na to da nam pokazatelji dohodovnoga siromaštva, subjektivnoga siromaštva i materijalne deprivacije ne pokazuju iste trendove (Slika 1 i Tablica 2), važno bi bilo provjeriti u kojoj se mjeri spomenute dimenzije siromaštva podudaraju. Stoga smo nastojali izjednačiti proporcije siromašnih prema ovim trima mjerama u 2008. godini. Definirajući prag materijalne deprivacije kao $87 \%$ medijana bodovne distribucije (umjesto $85 \%$ medijana), izjednačili smo proporcije dohodovno siromašnih i materijalno depriviranih u 2008. godini (17\%), ali to nije bilo moguće napraviti za subjektivno siromašne, pa je njihova proporcija ostala znatno veća nego drugih dviju skupina siromašnih (31\%).

Rezultati pokazuju da postoji prilično nepodudaranje između triju mjera ili dimenzija siromaštva (uzimajući u obzir i činjenicu da je nepodudaranje dijelom posljedica veće proporcije subjektivno siromašnih u odnosu na druge dvije skupine). Na primjer, $40 \%$ stanovništva siromašno je barem na jednoj dimenziji, oko $19 \%$ stanovnika siromašno je barem na dvije dimenzije, dok je 7,3\% građana siromašno na svim trima dimenzijama (Tablica 4). No to ne znači da spomenute mjere siromaštva nisu povezane. Omjeri šansi (odds ratios) u Tablici 3 pokazuju da siromašni na jednoj dimenziji (u odnosu na one koji nisu siromašni na toj dimenziji) imaju većih izgleda da će biti siromašni i na druge dvije dimenzije. Na primjer, dohodovno siromašni imaju oko 7,5 puta više izgleda da će biti materijalno deprivirani nego oni koji nisu dohodovno siromašni, iako su ti izgledi manji ako se uzme u obzir i subjektivno siromaštvo $(4,1)$. Materijalno deprivirani imaju veće izglede da će biti dohodovno siromašni nego subjektivno siromašni, dok dohodovno siromašni imaju više izgleda da će biti 
2 TABLICA 3

Omjeri izgleda siromaštva na drugim dimenzilama siromaštva (odds ratio)

$\rightarrow$ TABLICA 4

Kombinacije kumuliranje dimenzija siromaštva (2008.)

\begin{tabular}{|c|c|c|c|}
\hline & $\begin{array}{r}\text { Dohodovno } \\
\text { siromašni }\end{array}$ & $\begin{array}{r}\text { Subjektivno } \\
\text { siromašni }\end{array}$ & $\begin{array}{l}\text { Materijalno } \\
\text { deprivirani }\end{array}$ \\
\hline $\begin{array}{l}\text { Dohodovno } \\
\text { siromašni }\end{array}$ & & $\begin{array}{r}9,76^{* *} \\
(6,84)^{* *}\end{array}$ & $\begin{array}{r}7,56^{* *} \\
(4,12)^{* *}\end{array}$ \\
\hline $\begin{array}{l}\text { Subjektivno } \\
\text { siromašni }\end{array}$ & & & $\begin{array}{r}6,41^{* *} \\
(3,97)^{* *}\end{array}$ \\
\hline
\end{tabular}

Napomena: U zagradama su omjeri izgleda koji se dobiju kada se kontrolira preostala dimenzija siromaštva.

** $\mathrm{p}<0,01$

Neke razloge slaboga podudaranja između promatranih mjera objasnili su Bradshaw i Finch (2003.):

1) pojedinci mogu ostati bez posla ili biti umirovljeni, što znači da će vjerojatno biti dohodovno siromašni, ali ne i nužno materijalno deprivirani jer posjeduju materijalna dobra koja su stekli u boljim vremenima i, obrnuto, pojedinci koji su ranije bili nezaposleni zapošljavanjem mogu prestati biti dohodovno siromašni, ali mogu biti materijalno deprivirani jer nisu mogli kupiti nužna materijalna dobra u vrijeme nezaposlenosti i niskoga dohotka

2) razlog može biti i tzv. lažna svijest, neki se osjećaju subjektivno siromašno (iako to ne pokazuju objektivne mjere) jer imaju svoje razumijevanje pristojnoga životnog standarda, imaju visoke aspiracije i, obrnuto, neki se ne moraju osjećati deprivirano jer neka "nužna dobra" ne moraju biti prioritet za njih i njihovo kućanstvo.

\begin{tabular}{lrrrrr}
\hline Skupina & $\begin{array}{r}\text { Dohodovno } \\
\text { siromaštvo }\end{array}$ & $\begin{array}{r}\text { Subjektivno } \\
\text { siromaštvo }\end{array}$ & $\begin{array}{r}\text { Materijalna } \\
\text { deprivacija }\end{array}$ & $\begin{array}{r}\text { Stope } \\
(\%)\end{array}$ & $\mathrm{N}$ \\
\hline $\mathrm{A}$ & $\mathrm{Ne}$ & $\mathrm{Ne}$ & $\mathrm{Ne}$ & 60 & 5099 \\
$\mathrm{~B}$ & $\mathrm{Da}$ & $\mathrm{Ne}$ & $\mathrm{Ne}$ & 3,4 & 294 \\
$\mathrm{C}$ & $\mathrm{Ne}$ & $\mathrm{Ne}$ & $\mathrm{Da}$ & 4,6 & 394 \\
$\mathrm{D}$ & $\mathrm{Da}$ & $\mathrm{Ne}$ & $\mathrm{Da}$ & 1,1 & 91 \\
$\mathrm{E}$ & $\mathrm{Ne}$ & $\mathrm{Da}$ & $\mathrm{Ne}$ & 14,2 & 1220 \\
$\mathrm{~F}$ & $\mathrm{Da}$ & $\mathrm{Da}$ & $\mathrm{Ne}$ & 6,1 & 522 \\
$\mathrm{G}$ & $\mathrm{Ne}$ & $\mathrm{Da}$ & $\mathrm{Da}$ & 4,3 & 373 \\
$\mathrm{H}$ & $\mathrm{Da}$ & $\mathrm{Da}$ & $\mathrm{Da}$ & 7,3 & 627 \\
\hline
\end{tabular}

Izvor: APK, autorovi izračuni.

Ako polazimo od toga da oslanjanje samo na jednu mjeru siromaštva ne daje pravu sliku siromaštva, onda bi kumulativni pristup bio adekvatniji način identifikacije rizičnih skupina 
DRUŠ. ISTRAŽ. ZAGREB GOD. 21 (2012),

BR. $3(117)$

STR. 607-629

ŠUĆUR, Z.:

STAGNIRA LI DOISTA..
(Bradshaw i Finch, 2003.). Naime, logično bi bilo pretpostaviti da su "istinski siromašni" (truly poor) oni koji su siromašni na više dimenzija ili mjera siromaštva. U nepovoljnijoj i goroj situaciji bili bi oni koji su istodobno i dohodovno siromašni i materijalno deprivirani, oni koji su samo dohodovno siromašni, dok bi u najgoroj situaciji bili oni koji su siromašni prema svim pokazateljima (u našem slučaju, dohodovno su siromašni, materijalno deprivirani i sami sebe percipiraju siromašnima). Dakle, možemo pretpostaviti da su oni koji su siromašni prema više dimenzija uistinu siromašni te, $\mathrm{s}$ druge strane, da je njihovo siromaštvo teže (tj. da žive $\mathrm{u}$ dubinskom, a ne $u$ površinskom, siromaštvu). Da bismo provjerili ovu pretpostavku, $u$ idućem poglavlju analizirat ćemo obilježja (profile) siromašnih prema pojedinim dimenzijama i njihovoj kombinaciji.

Zatim, osim kriterija kumulacije dimenzija, može se raspravljati o tome je li jedna mjera siromaštva važnija od druge. Na primjer, teško je zamisliti da netko tko živi u (dubinskom) siromaštvu neće sebe percipirati siromašnim, tako da subjektivni osjećaj siromaštva, kako navode Bradshaw i Finch (2003.), jest "nužan, ali ne i dovoljan, uvjet" da bismo nekoga smatrali siromašnim.

Ako se osvrnemo na dimenzije siromaštva i njihovu kombinaciju (Tablica 4), onda najbrojniju skupinu (60\%) čine građani koji nisi siromašni ni na jednoj od triju dimenzija (skupina A), na drugom su mjestu po brojnosti oni koji su samo subjektivno siromašni (skupina E), zatim slijede oni koji su siromašni na sve tri dimenzije (skupina H). Oni koji su istodobno dohodovno i subjektivno siromašni (skupina F) čine $6,1 \%$ stanovništva. Samo materijalno deprivirani (skupina C) čine 4,6\% stanovništva, a iza njih odmah slijede oni koji su istodobno materijalno deprivirani i subjektivno siromašni (skupina G). Na kraju su oni koji su samo dohodovno siromašni (skupina B) te oni koji su dohodovno siromašni i materijalno deprivirani, ali nisu subjektivno siromašni (skupina D). U idućem poglavlju analizirat ćemo osnovna sociodemografska obilježja prije navedenih skupina, kako bismo utvrdili razlike u profilu siromaštva ovisno o primijenjenim mjerama siromaštva.

\section{Obilježja siromašnih i/ili materijalno depriviranih}

Da bismo utvrdili razlike $u$ obilježjima siromašnih ovisno o kombinaciji dimenzija siromaštva, koristili smo se multinomnom logističkom regresijom. Za razliku od binarne logističke regresije, multinomna regresija dopušta da zavisna varijabla ima više od dvije kategorije. U našem slučaju zavisna je varijabla nominalnoga tipa i sastoji se od 8 kategorija iz Tablice 4, 
DRUŠ. ISTRAŽ. ZAGREB GOD. 21 (2012), BR. $3(117)$

STR. 607-629

ŠUĆUR, Z.:

STAGNIRA LI DOISTA... s tim da je skupina ispitanika koji nisu bili siromašni ni na jednoj dimenziji uzeta kao referentna kategorija, tj. svi dobiveni rezultati za druge kategorije uspoređivani su s ovom kategorijom. Multinomna regresija omogućuje nam da izmjerimo utjecaj skupine faktora (nezavisnih varijabli) na vjerojatnost pripadanja pojedinoj kategoriji zavisne varijable. U regresijski model uvršteno je 6 nezavisnih varijabli kategorijalnoga tipa. Utjecaj svake kategorije procjenjivan je u odnosu na referentnu kategoriju pojedine nezavisne varijable te $u$ odnosu na referentnu skupinu zavisne varijable (pojedinci koji nisu siromašni ni na jednoj dimenziji). Ako uzmemo u obzir svih 6 nezavisnih varijabli, onda u našem modelu referentnu grupu čine: osobe muškoga spola od 25 do 49 godina, koje su zaposlene u punom radnom vremenu, žive u kućanstvu s jednom ili više odraslih osoba (sve mlađe od 65 godina), u kojem jedan član ima višu ili visoku stručnu spremu te koje živi samo od plaće (bez mirovina).

U Tablici 5 prikazani su koeficijenti koji predstavljaju omjere relativnih rizika određene skupine $\mathrm{u}$ odnosu na referentnu kategoriju nezavisne varijable i referentnu skupinu zavisne varijable. Ako je taj omjer veći od 1, onda je vjerojatnost pojave rizika siromaštva na pojedinim dimenzijama ili njihovoj kombinaciji u toj grupi veća od vjerojatnosti pojave istih tih rizika u referentnoj grupi. Situacija je obrnuta u slučaju kada je taj omjer manji od 1.

Prije svega proizlazi da je spol jedina nezavisna varijabla koja nije statistički značajno povezana s rizikom siromaštva, bez obzira na to preko kojih pokazatelja siromaštvo mjerili. Iako su profili siromaštva relativno stabilni, postoje razlike $\mathrm{u}$ obilježjima siromašnih s obzirom na mjere siromaštva. Starije osobe češće su višestruko deprivirane i imaju veće izglede da budu objektivno, ali ne i subjektivno, siromašne, za razliku od drugih dobnih skupina. Poglavito starije osobe bez mirovina koje žive samački imaju skromnije percepcije pristojnoga životnog standarda i niže aspiracije. Ako se analiziraju visine omjera izgleda iz Tablice 5, onda je primjetno da se na većini nezavisnih varijabli kumulativno siromašni (siromašni na sve tri dimenzije) najviše razlikuju od nesiromašnih (onih koji nisu siromašni ni na jednoj dimenziji) te da se osobe koje su siromašne na dvije dimenzije siromaštva (bez obzira na kombinaciju) više razlikuju od nesiromašnih nego siromašni samo na jednoj dimenziji. Tako osoba koja živi u kućanstvu bez članova s višom ili visokom stručnom spremom ima 2 do 5,5 puta više izgleda da bude siromašna na jednoj ili na dvije dimenzije siromaštva, a čak 14,5 puta ima veće izglede da bude siromašna na sve tri dimenzije nego referentna grupa. U odnosu na ostale skupine, veće izglede da postanu kumu- 
(4) TABLICA 5

Omjeri izgleda siromaštva i/ili materijalne deprivacije (multinomni regresijski model) lativno siromašni ili siromašni prema svim dimenzijama imaju samačka kućanstva i kućanstva bez djece, starije osobe ili ostale neaktivne osobe bez mirovina i ikakvih tržišnih primanja, osobe koje su nezaposlene ili nedovoljno uposlene i žive u kućanstvima u kojima nema članova s višom ili visokom stručnom spremom.

\begin{tabular}{|c|c|c|c|c|c|c|c|}
\hline $\begin{array}{r}\text { Dohc } \\
\text { sir }\end{array}$ & $\begin{array}{l}\text { lodovno } \\
\text { romašni }\end{array}$ & $\begin{array}{r}\text { Subjektivno } \\
\text { siromašni }\end{array}$ & $\begin{array}{l}\text { Materijalno } \\
\text { deprivirani }\end{array}$ & $\begin{array}{r}\text { Dohodovno } \\
\text { i subjektivno } \\
\text { siromašni }\end{array}$ & $\begin{array}{r}\text { Dohodovno } \\
\text { siromašni i } \\
\text { materijalno } \\
\text { deprivirani }\end{array}$ & $\begin{array}{r}\text { Subjektivno } \\
\text { siromašni i } \\
\text { materijalno } \\
\text { deprivirani }\end{array}$ & $\begin{array}{r}\text { Dohodovno } \\
\text { i subjektivno } \\
\text { siromašni te } \\
\text { materijalno } \\
\text { deprivirani }\end{array}$ \\
\hline \multicolumn{8}{|l|}{ Spol } \\
\hline Ž & 0,87 & 0,99 & 0,98 & 0,85 & 0,78 & 0,9 & 0,83 \\
\hline \multicolumn{8}{|l|}{ Dob } \\
\hline-18 & 0,85 & 0,8 & 1,25 & 0,78 & 0,32 & 1,09 & 0,71 \\
\hline $19-24$ & 1,01 & 0,93 & $1,97^{* *}$ & 0,97 & 0,99 & 1,26 & $0,58^{*}$ \\
\hline $50-64$ & 1,05 & 1,16 & 1,13 & $1,53^{* *}$ & 2,52 & 1,11 & 1,06 \\
\hline $65+$ & 1,03 & 0,99 & 1,57 & $1,85^{* *}$ & $5,06^{* *}$ & 0,85 & $2,00^{* *}$ \\
\hline \multicolumn{8}{|l|}{ Broj ukućana s VŠ/VSS } \\
\hline 0 & $3,02^{* *}$ & $2,01^{* *}$ & $2,00^{* *}$ & $5,45^{* *}$ & $5,59^{* *}$ & $3,49^{* *}$ & $14,45^{* *}$ \\
\hline $2+$ & 0,74 & $0,41^{* *}$ & 0,86 & $\ldots$ & $\ldots$ & 0,66 & 0,7 \\
\hline \multicolumn{8}{|l|}{ Radni status } \\
\hline Samozaposlen & $3,15^{* *}$ & $0,69^{*}$ & $1,57^{*}$ & $4,32^{* *}$ & 1,02 & $1,70^{*}$ & $4,40^{* *}$ \\
\hline Privremeno zaposlen & $4,43^{* *}$ & $2,07^{* *}$ & $2,39 * *$ & $3,14^{* *}$ & 1,66 & $3,14^{* *}$ & $5,55^{* *}$ \\
\hline Nezaposlen & $3,10^{* *}$ & $2,08^{* *}$ & 0,52 & $6,33^{* *}$ & 1,46 & 1,49 & $5,91^{* *}$ \\
\hline Umirovljenik & 1,28 & 0,91 & 0,96 & 0,76 & 0,59 & 1,27 & 0,98 \\
\hline Ostali radno neaktivni & $3,35^{* *}$ & $1,50^{* *}$ & 1,11 & $3,28^{* *}$ & 2,64 & 1,34 & $4,44^{* *}$ \\
\hline \multicolumn{8}{|l|}{ Izvor prihoda } \\
\hline Bez plaća i mirovina & $10,98^{* *}$ & $5,66^{* *}$ & $16,14^{* *}$ & $22,51^{* *}$ & $17,06^{* *}$ & $4,01^{* *}$ & $63,69^{* *}$ \\
\hline Samo mirovine & $5,48^{* *}$ & $1,48^{* *}$ & 1,06 & $5,99 * *$ & 2,66 & 0,91 & $5,32 * *$ \\
\hline Plaće + mirovine & 1,27 & $1,43^{* *}$ & 0,79 & 0,85 & $0,23^{* *}$ & 0,84 & 1,23 \\
\hline \multicolumn{8}{|l|}{ Tip kućanstva } \\
\hline Samac & 1,41 & 1,17 & $2,75^{* *}$ & $2,3^{* *}$ & $15,43^{* *}$ & $2,24^{* *}$ & $2,68^{* *}$ \\
\hline 2 odraslih (jedan $65+$ ) & 0,69 & 1,17 & 1,05 & 1,21 & $8,94^{* *}$ & $1,87^{* *}$ & 1,06 \\
\hline 1 odrasli + djeca & $2,14^{* *}$ & $1,51^{*}$ & 0,51 & $2,83^{* *}$ & 3,79 & 0,71 & 1,7 \\
\hline 2 odraslih $+1-2$ djece & 1,14 & 1,07 & $0,62^{* *}$ & 1,2 & 1,26 & $0,62^{* *}$ & $0,66^{* *}$ \\
\hline 2 odraslih +3 i više djece & 0,55 & 1,17 & 0,67 & $2,17^{* *}$ & $11,14^{* *}$ & 0,68 & 1,16 \\
\hline
\end{tabular}

Izvor: APK, autorovi izračuni. ${ }^{* *} \mathrm{p}<0,01 ;{ }^{*} \mathrm{p}<0,05$

Ako kumulativni pristup mjerenju siromaštva daje realnije procjene i profil siromaštva, postavlja se pitanje što se događalo s kumulativnim siromaštvom od 2003. do 2008. godine. Ovdje pod kumulativno siromašnima razumijevamo one koji su siromašni prema sve tri mjere siromaštva. Slika 2 još jednom potvrđuje naše ranije nalaze koji pokazuju da je od 2003. do 2008. siromaštvo u Hrvatskoj smanjeno. Naime, udio onih koji su istodobno dohodovno i subjektivno siromašni te materijalno deprivirani smanjio se za trećinu u 2008. u odnosu na 2003. godinu. 
$\rightarrow$ SLIKA 2

Kumulativno siro

maštvo* u Hrvatsko

(2003.-2008.)

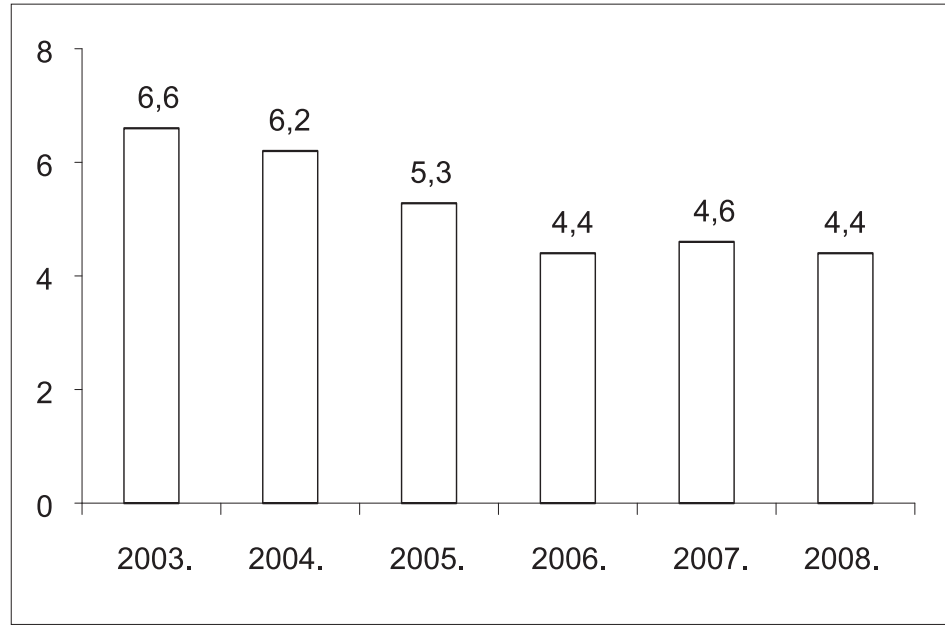

*Istodobna kombinacija dohodovnoga siromaštva, subjektivnoga siromaštva i materijalne deprivacije. Prag materijalne deprivacije određen je kao 85\% medijana na bodovnoj distribuciji. Izvor: APK, autorovi izračuni.

\section{ZAKLJUČAK}

Osnovni je cilj ovoga rada bio utvrditi što se događalo sa siromaštvom u Hrvatskoj između 2003. i 2008. godine te kako objasniti činjenicu da su stope relativnoga siromaštva ostale približno iste u cijelom razdoblju unatoč visokim stopama ekonomskog rasta. U tom su pogledu uzeti alternativni pokazatelji dohodovnoga i subjektivnoga siromaštva te materijalne deprivacije. Za razliku od stopa siromaštva dobivenih na temelju linije siromaštva definirane kao $60 \%$ medijana nacionalnoga dohotka, koje su bile stagnantne, alternativne mjere siromaštva (linija siromaštva fiksirana u određenoj vremenskoj točki, subjektivno siromaštvo i materijalna deprivacija) pokazale su da je od 2003. do 2008. došlo do značajnoga smanjenja opsega siromaštva. Na to upućuju i istraživanja Svjetske banke o kretanju apsolutnoga siromaštva na temelju potrošnje (World Bank, 2006., 2010.), s tim da nam istraživanja Svjetske banke ne omogućuju kontinuirano praćenje siromaštva u cijelom razdoblju od 2003. do 2008. Tako je stopa apsolutnoga siromaštva u 2004. u odnosu na 2003. godinu smanjena za 1,3 postotna boda (World Bank, 2006.). Naknadni izračuni stopa apsolutnoga siromaštva sugeriraju da je ona mogla pasti sa $11 \%$ u 2004. na $6 \%$ do $8 \%$ u 2008. godini (World Bank, 2010.).

Osim analize pokazatelja siromaštva prema pojedinim dimenzijama, upotrijebljen je i kumulativni pristup mjerenju siromaštva, tj. siromaštvo je mjereno prema kombinaciji više dimenzija ili mjera siromaštva. Pošlo se od pretpostavke da su $\mathrm{u}$ težoj situaciji oni koji su siromašni na više dimenzija od o- 
DRUŠ. ISTRAŽ. ZAGREB GOD. 21 (2012),

BR. 3 (117),

STR. 607-629

ŠUĆUR, Z.:

STAGNIRA LI DOISTA... nih koji su siromašni samo na jednoj dimenziji te da su neke dimenzije siromaštva važnije od drugih. Na temelju kumulativnoga pristupa, potvrđena je i teza da se siromaštvo između 2003. i 2008. godine smanjilo.

Ustanovljeno je da ne postoji potpuno preklapanje između dimenzija siromaštva, ali siromašni na jednoj dimenziji (u odnosu na one koji nisu siromašni na toj dimenziji) imaju veće izglede da će biti siromašni i na drugim dimenzijama siromaštva. Razne mjere siromaštva rezultiraju različitim profilom siromaštva, što utječe na identifikaciju siromašnih i planiranje mjera socijalne politike. Sociodemografska obilježja objektivno siromašnih razlikuju se od sociodemografskih obilježja subjektivno siromašnih, kao što se profil siromaštva onih koji su siromašni na sve tri dimenzije razlikuje od profila siromaštva onih koji su siromašni na jednoj ili dvije dimenzije. Pokazalo se da se siromašni prema sva tri pokazatelja najviše razlikuju od nesiromašnih i ostalih skupina siromašnih te da veću vjerojatnost pripadanja ovoj skupini imaju starije i druge neaktivne osobe bez ikakvih primanja, nezaposlene i nedovoljno uposlene osobe koje žive u kućanstvima bez članova s višom ili visokom stručnom spremom, samačka kućanstva i kućanstva bez djece.

Rezultati ovog rada slični su rezultatima istraživanja iz 2004. godine (Šućur, 2006.b), koje je imalo za cilj utvrditi raširenost objektivnoga, subjektivnoga siromaštva, materijalne deprivacije i socijalne isključenosti u Hrvatskoj. Oba istraživanja pokazala su da je koncentracija dimenzija siromaštva i deprivacije karakteristična za relativno malen dio hrvatskoga stanovništva. U istraživanju Z. Šućura (2006.b), 61\% stanovništva nije bilo siromašno ni na jednoj dimenziji, dok je $5 \%$ bilo deprivirano na tri ili četiri dimenzije. Prema rezultatima ovoga istraživanja, u 2008. godini $60 \%$ građana nije bilo siromašno ni na jednoj dimenziji, a 7,3\% bilo je siromašno na sve tri dimenzije.

Ovaj je rad pokazao da je prilikom praćenja siromaštva nužno uzeti u obzir više mjera siromaštva i kumulativni pristup, jer se na taj način može bolje utvrditi ne samo opseg nego i dubina siromaštva (važno je u situaciji oskudnih financijskih resursa razlikovati one koji žive u površinskom siromaštvu od onih koji žive u dubinskom siromaštvu).

Osnovni metodološki problem ovog istraživanja jest izbor pokazatelja materijalne deprivacije i određivanje pragova (indeksa) deprivacije. U budućim istraživanjima treba proširiti krug pokazatelja, kako bi se pokrio veći broj područja minimalno pristojnoga životnog standarda, a ne samo infrastruktura i posjedovanje trajnijih kućanskih dobara. Pritom bi također bilo važno prikupiti mišljenja građana o tome koja dobra, 
DRUŠ. ISTRAŽ. ZAGREB GOD. 21 (2012), BR. 3 (117)

STR. 607-629

ŠUĆUR, Z.

STAGNIRA LI DOISTA... usluge i aktivnosti oni smatraju nužnima i prijeko potrebnima u Hrvatskoj te razlučiti utjecaj preferencija od ekonomske oskudice na stil života. Na kraju, bilo bi poželjno dimenzije siromaštva pratiti duže na temelju istih pokazatelja kako bi se mogli utvrditi trendovi.

\section{LITERATURA}

Ayala, L., Jurado, A. i Pérez-Mayo, J. (2009.), Income Poverty and Multidimensional Deprivation: Lessons from Cross-Regional Analysis. ECINEQ WP 2009-106, 21p.

Berthoud, R. i Bryan, M. (2011.), Income, Deprivation and Poverty: A Longitudinal Analysis. Journal of Social Policy, 40 (1): 135-156. doi:10.1017/S0047279410000504

Böhnke, P. (2008.), Are the Poor Socially Integrated? The Link between Poverty and Social Support in Different Welfare Regimes. Journal of European Social Policy, 18 (2): 133-150. doi:10.1177/095892870 7087590

Bossert, W., Chakravarty, S. R. i D'Ambrosio, C. (2009.), Multidimensional Poverty and Material Deprivation. ECINEQ WP 2009-129, 21p.

Bradshaw, J. i Finch, N. (2003.), Overlaps in Dimensions of Poverty. Journal of Social Policy, 32 (4): 513-525. doi:10.1017/S004727940300713X

Council of Ministers (1985.), Council Decision of 19 December 1984 on Specific Community Action to Combat Poverty (85/8/EEC), OJEC, L 2, Brussels.

Desai, M. i Shah, A. (1988.), An Econometric Approach to the Measurement of Poverty. Oxford Economic Papers, 40 (3): 505-522.

Dickes, P., Fusco, A. i Marlier, E. (2010.), Structure of National Perceptions of Social Needs across EU Countries. Social Indicators Research, 95 (1): 143-167. doi:10.1007/s11205-009-9454-5

Državni zavod za statistiku (2006.), Pokazatelji siromaštva od 2003. do 2005. Priopćenje, br. 14.1.2.

Državni zavod za statistiku (2009.), Pokazatelji siromaštva od 2006. do 2008. Priopćenje, br. 14.1.2.

European Commission (2007.), Poverty and Social Exclusion. Report on the Special Eurobarometer 279/ Wave 67.1.

European Commission (2009.), Portfolio of Indicators for the Monitoring of the European Strategy for Social Protection and Social Inclusion - 2009 update. Brussels, EC.

Fusco, A., Guio, A.-C. i Marlier, E. (2011.), Income Poverty and Material Deprivation in European Countries, Working Paper, No. 2011-04, Luxembourg, CEPS/INSTEAD.

Guio, A.-C. (2005.), Material Deprivation in the EU, Statistics in Focus, Population and Social Conditions, Living Conditions and Welfare, 21/2005, Luxembourg, Eurostat.

Guio, A.-C. (2009.), What Can Be Learned from Deprivation Indicators in Europe?, Eurostat Methodologies and Working Paper, 40 p., Luxembourg, Eurostat. http://epp.eurostat.ec.europa.eu/cache/ITY_OFFPUB/ KS-RA-09-007/EN/KS-RA-09-007-EN.PDF (5. 9. 2011.) 
DRUŠ. ISTRAŽ. ZAGREB GOD. 21 (2012) BR. 3 (117),

STR. $607-629$

ŠUĆUR, Z. STAGNIRA LI DOISTA...
Guio, A.-C., Fusco, A. i Marlier, E. (2009.), An EU Approach to Material Deprivation Using EU-SILC and Eurobarometer Data, IRISS Working Paper, No. 2009-19, Luxembourg, CEPS/INSTEAD.

Halleröd, B. (1995.), The Truly Poor: Direct and Indirect Measurement of Consensual Poverty in Sweden. Journal of European Social Policy, 5 (2): 111-129. doi:10.1177/095892879500500203

Kenworthy, L. (2007.), Measuring Poverty and Material Deprivation. Report prepared for Statistics Canada, http://www.u.arizona.edu/ lkenwor/ measuringpovertyandmaterialdeprivation2007.pdf (3. 9. 2011.)

Mack, J. i Lansley, S. (1985.), Poor Britain, London, George Allen \& Unwin.

Notten, G. i De Neubourg, C. (2007.), The Policy Relevance of Absolute and Relative Poverty Headcounts: What's in a Number? Working Paper MGSoG/2007/WP006. Maastricht University, Maastricht Graduate School of Governance.

Perry, B. (2002.), The Mismatch between Income Measures and Direct Outcome Measures of Poverty. Social Policy Journal of New Zealand, (19): 101-127.

Ringen, S. (1988.), Direct and Indirect Measures of Poverty. Journal of Social Policy, 17 (3): 357-366. doi:10.1017/S0047279400016858

Šućur, Z. (2001.), Siromaštvo, Zagreb, Pravni fakultet.

Šućur, Z. (2006.a), Objektivno i subjektivno siromaštvo u Hrvatskoj. Revija za socijalnu politiku, 13 (3-4): 237-255.

Šućur, Z. (2006.b), Siromaštvo, višedimenzionalna deprivacija i socijalna isključenost u Hrvatskoj. Revija za sociologiju, 36 (3-4): 131-147.

Tomlinson, M., Walker, R. i Williams, G. (2008.), Measuring Poverty in Britain as a Multi-Dimensional Concept, 1991 to 2003. Journal of Social Policy, 37 (4): 597-620. doi: 10.1017/S0047279408002237

Townsend, P. (1979.), Poverty in the United Kingdom, Hardmonsworth, Penguin Books.

Townsend, P. i Gordon, D. (1991.), What is Enough? New Evidence on Poverty Allowing the Definition of a Minimum Benefit. U: M. Adler, C. Bell, J. Clasen i A. Sinfield (ur.), The Sociology of Social Security (str. 35-69), Edinburgh, Edinburgh University Press.

Tsakloglou, P. i Papadopulos, F. (2002.a), Poverty, Material Deprivation and Multi-Dimensional Disadvantage during Four Life Stages: Evidence from the ECHP. U: M. Barnes, C. Heady, S. Middleton, J. Millar, F. Papadopulos, G. Room i P. Tsakloglou, Poverty and Social Exclusion in Europe (str. 24-52), Cheltenham, Northampton, Edward Elgar.

Tsakloglou, P. i Papadopulos, F. (2002.b), Aggregate Level and Determining Factors of Social Exclusion in Twelve European Countries. Journal of European Social Policy, 12 (3): 211-225. doi:10.1177/095287 2002012003394

Whelan, C., Layte, R. i Maitre, B. (2003.), Persistent Income Poverty and Deprivation in the European Union: An Analysis of the First Three Waves of the European Community Household Panel. Journal of Social Policy, 32 (1): 1-18. doi:10.1017/S0047279402006864 
DRUŠ. ISTRAŽ. ZAGREB GOD. 21 (2012), BR. $3(117)$

STR. $607-629$

ŠUĆUR, Z: STAGNIRA LI DOISTA...
Whelan, C., Layte, R. i Maitre, B. (2004.), Understanding the Mismatch Between Income Poverty and Deprivation: A Dynamic Comparative Analysis. European Sociological Review, 20 (4): 287-302. doi:10.1093/esr/jch029

Whelan, C. T., Layte, R., Maître, B. i Nolan, B. (2001.), Income, Deprivation and Economic Strain. An Analysis of the ECHP. European Sociological Review, 17 (4): 357-372. doi:10.1093/esr/17.4.357

Whelan, C. T., Nolan, B. i Maître, B. (2008.), Measuring Material Deprivation in an Enlarged EU, ESRI Working Paper No. 249.

World Bank (2006.), Croatia: Living Standards Assessment, Volume 2: Background Papers, Washington, World Bank.

World Bank (2010.), Croatia: Social Impact of the Crisis and the Policy Response - An Assessment, Washington, World Bank.

\section{Has Poverty in Croatia Been Really Stagnant?}

\author{
Zoran ŠUĆUR \\ Faculty of Law, Zagreb
}

The main goal of the paper was to compare poverty rates in Croatia based on the EU poverty methodology $160 \%$ of median equivalent income) with alternative indicators of income poverty, material deprivation and subjective poverty. Together with poverty indicators referring to different dimensions of poverty, the cumulative approach to poverty was used, meaning that poverty was measured by combining more dimensions of poverty. The Household Budget Survey in the 2003-2008 period was used as a data source. All alternative poverty indicators, as well as cumulative poverty indicators, confirmed that the scope of poverty was significantly reduced in the 2003-2008 period (the rates of material deprivation were almost halved), being at odds with stagnant relative poverty rates (obtained according to the poverty line defined as $60 \%$ of median). There has been a lack of absolute overlap among poverty dimensions (measures), but dimensions are interrelated. Different poverty measures result in different poverty profiles. The paper has shown that it is necessary to use more poverty measures and cumulative approach in order to monitor poverty, because this way it is possible to identify much better not only the scope but also the depth of poverty.

Keywords: poverty, material deprivation, cumulative approach, Croatia 